\title{
Weight and height prediction of immobilized patients
}

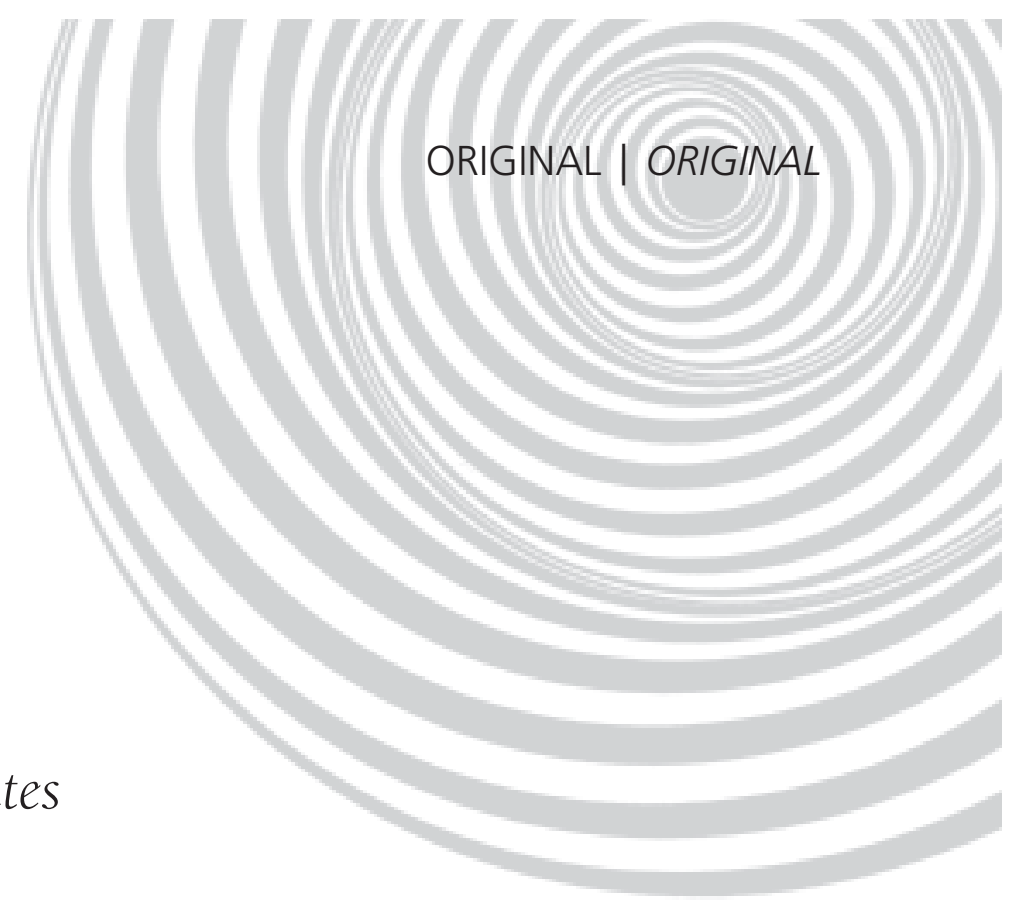

\author{
Estela Iraci RABITO1,2 \\ Gabriela Bergamini VANNUCCHI 2,3 \\ Vivian Marques Miguel SUEN ${ }^{4}$ \\ Laércio Lopes Castilho NETO ${ }^{5}$ \\ Júlio Sérgio MARCHINI 2,4
}

A B S T R A C T

\section{Objective}

To confirm the adequacy of the formula suggested in the literature and/or to develop appropriate equations for the Brazilian population of immobilized patients based on simple anthropometric measurements.

\section{Methods}

Hospitalized patients were submitted to anthropometry and methods to estimate weight and height of bedridden patients were developed by multiple linear regression.

\section{Results}

Three hundred sixty eight persons were evaluated at two hospital centers and five weight-pre-dicting and two height-predicting equations were developed from the measurements ob-tained. Among the new equations developed, the simplest one for weight estimate was: Weight $(\mathrm{kg})=0.5759 \times($ arm circumference, $\mathrm{cm})+0.5263$ $\mathrm{x}($ abdominal circumference, $\mathrm{cm})+1.2452 \times($ calf circumference, $\mathrm{cm})-4.8689 \times($ Sex, male $=1$ and female $=2)$ $-32.9241(r=0.94)$; and the one for height estimate was: Height $(\mathrm{cm})=58.6940-2.9740 \times($ Sex $)-0.0736 x$ (age, years) $+0.4958 \times($ arm length, $\mathrm{cm})+1.1320 \times$ (half- span, $\mathrm{cm})(\mathrm{r}=0.88)$. The estimates thus calculated did not differ significantly from actual measurements, with $p=0.94$ and 0.89 and a mean error of 6.0 and $2.1 \%$ for weight and height, respectively.

\footnotetext{
1 Curso de Nutrição, Faculdade Evangélica do Paraná. Curitiba, PR, Brasil.

2 Laboratório de Espectrometria de Massa, Faculdade de Medicina de Ribeirão Preto, Universidade de São Paulo. Ribeirão Preto, SP, Brasil.

${ }^{3}$ Divisão de Nutrição e Dietética, Hospital Universitário Evangélico de Curitiba. Curitiba, PR, Brasil.

${ }^{4}$ Departamento de Clínica Médica, Disciplina de Nutrologia, Hospital de Clínicas da Faculdade de Medicina de Ribeirão Preto, Universidade de São Paulo. Av. Bandeirantes, 3900, 14049-900, Ribeirão Preto, SP, Brasil. Correspondência para/Correspondence to: J.S. MARCHINI.

${ }^{5}$ Curso de Medicina, Faculdade de Medicina de Ribeirão Preto, Universidade de São Paulo. Ribeirão Preto, SP, Brasil.
} 


\section{Conclusion}

We suggest that these equations can be used to estimate the weight and height of bedridden patients when necessary or when these parameters cannot be measured with a scale and a stadiometer.

Indexing terms: body weight; body height; anthropometry; linear models.

\section{R E S U M O}

\section{Objetivo}

Verificar a adequação das fórmulas sugeridas na literatura, e desenvolver equações preditivas de peso e altura para a população hospitalizada brasileira, a partir de medidas antropométricas usuais.

\section{Métodos}

Realizou-se antropometria e bioimpedância de pacientes hospitalizados. Por meio de regressão linear múltipla, desenvolveram-se fórmulas com o objetivo de prever o peso e a altura. Os resultados foram comparados com os obtidos de fórmulas da literatura e com as medidas reais.

\section{Resultados}

Foram avaliadas 368 pacientes e desenvolvidas equações preditivas do peso e da altura, ou seja: para estimativa de peso, peso $(\mathrm{kg})=0,5759 \times$ (circunferência do braço, $\mathrm{cm})+0,5263 \times$ (circunferência abdominal, $\mathrm{cm}$ ) + 1,2452 $x$ (circunferência da panturrilha, cm) -4,8689 x (Sexo, masculino= 1 feminino= 2) $-32,9241(r=0,94, p<0.001)$; e altura $(\mathrm{cm})=58,6940-2,9740 \times($ Sexo $)-0,0736 \times$ (idade, anos) + 0,4958 x (comprimento do braço, $\mathrm{cm})+1,1320 \times$ (meia envergadura, $\mathrm{cm})(r=0,88, p<0.001)$. As estimativas realizadas foram estatisticamente semelhantes às medidas reais, $p=0,94$ e 0,89 e erro médio de 6,0\% e 2,1\%, respectivamente para o peso e altura. Quando aplicadas as formulas preconizadas pela literatura, os resultados encontrados foram estatisticamente diferentes do real $(p<0,001)$.

\section{Conclusão}

Sugere-se que estas equações sejam utilizadas para prever peso e altura de pacientes acamados.

Termos de indexação: peso corporal; estatura; modelos lineares.

\section{NTRODUCTION}

Body weight, in addition to being an indicator of nutritional status, is necessary for drug and nutrient therapy prescription. Regarding weight, for example, it is not only possible to estimate energy expenditure, but also to plan the amount of nutrients, such as protein and lipids, for enteral/parenteral nutritional therapy. Weight is also fundamental for the pharmacological prescription of drugs ${ }^{1}$ for both clinically stable and intensive care patients. Literature data ${ }^{2}$ indicate that errors of calculation occur when weight and height are estimated only by visual observation.

Anthropometry, which is a simple, noninvasive and objective method for the nutritional evaluation of patients, can be used to determine the adequacy of the main body components ${ }^{3}$. The use of anthropometric measurements to predict body weight of bedridden immovable patients has been reported ${ }^{4}$, but the equation proposed was created by measuring elderly American individuals, and cannot be generalized to other groups of patients.

Thus, the objective of the present study was to propose equations based on the anthropometric data of hospitalized immovable Brazilian patients that would be most appropriate to predict body weight and height. In addition, we intend to examine and compare the adequacy of the formulas already proposed in the literature against the current values.

\section{METHODS}

The patients were submitted to anthropometry and bioimpedance and the results 
were analyzed statistically in order to obtain predictive formulas for weight and height. The measurements were made on the wards of the Hospital das Clínicas, Faculdade de Medicina de Ribeirão Preto, Universidade de São Paulo, and at the Hospital Universitário Evangélico de Curitiba, Brazil, over a period of 4 months. The study was approved by the Ethics Committee of both institutions and all patients gave written informed consent to participate. All measurements were made only once by two duly trained professionals.

All patients, of both sexes, older than 18 years and able to walk were selected at random. Those with amputated or immobilized limbs, pregnant women, puerperae, patients with edema and/or ascites were excluded.

The patients were evaluated under fasting conditions. The measurements were made on the left side of the body in triplicate and the mean value was calculated. The parameters measured were:

a) height $(\mathrm{H}, \mathrm{Cm})$ and weight $(\mathrm{W}, \mathrm{kg})^{5}$ using a stadiometer and a platform scale with $0.1 \mathrm{~cm}$ and $100 \mathrm{~g}$ divisions, respectively; stadiometer;

b) knee height $(\mathrm{KH}, \mathrm{cm})^{6}$ using a children's

c) arm length $(A L, c m)^{7}$, calf circumference $(C C, \mathrm{~cm})^{4}$, arm circumference $(A C, \mathrm{~cm})^{7}$, abdominal circumference $(\mathrm{AbC}, \mathrm{cm})^{5}$, and half-span (HS, $(\mathrm{cm})^{8}$, using a rigid tape with $0.1 \mathrm{~cm}$ graduation;

d) bicipital (BST), tricipital (TSF), suprailiac (IST), subscapular (SST) skinfold thickness ${ }^{9}(\mathrm{~mm})$ and thickness of the adductor muscle of the thumb (AMT) $(\mathrm{mm})^{10}$ were measured with a calibrated caliper with a constant pressure of $10 \mathrm{~g} / \mathrm{mm}^{2}$;

e) electrical bioimpedance was measured with a Quantum BIA 101 Q instrument, RJL Systems, Michigan, USA, which uses a current of 800 micro-amperes and $50 \mathrm{kHz}$, to obtain resistance $(\operatorname{Re}, \Omega)$ and reactance $(\mathrm{Rc}, \Omega)^{11}$. Patients receiving intravenous hydration were excluded

The equations for height and weight prediction were obtained by multiple linear regression. The first step was to determine which of the above variables were correlated with weight or height. After the equations were established, the residues (errors) between the actual measurements and the estimated ones were calculated and were compared by the paired " $\mathrm{t}$ " test against the actual value ${ }^{12}$.

The results obtained with these equations were compared to those obtained with the formulas suggested in the literature ${ }^{4,6}$ as follows:

$$
\begin{aligned}
& H(\mathrm{~cm})=64.19-(0.04 \times \text { Age })+(2.02 \times \mathrm{KH}) ; \\
& H(\mathrm{~cm})=84.88-(0.24 \times \text { Age })+(1.83 \times \mathrm{KH}) ; \\
& H(\mathrm{~cm})=2 \times \text { half-span }{ }^{8} . \\
& W(\mathrm{~kg})=(1.73 \times \mathrm{AC})+(0.98 \times \mathrm{CC})+(0.37 \times
\end{aligned}
$$$$
\mathrm{SST})+(1.16 \times \mathrm{KH})-81.69 \text {; }
$$

$W(\mathrm{~kg})=(0.98 \times A C)+(1.27 \times C C)+(0.40$ $x$ SST $)+(0.87 x \mathrm{KH})-62.35$, for men and women, respectively.

\section{RESULTS}

The study was conducted on 368 patients (47\% females) proportionally divided among the study sites. The mean age of the sample (standard deviation SD) was $49, S D=17$ years (Table 1). Among the anthropometric and bioimpedance measurements, the variables showing a significant positive correlation $(p<0,05)$ with weight were height, resistance, abdominal circumference, arm circumference, calf circumference, and subscapular skinfold thickness. The variables that significantly correlated $(p<0,05)$ with height were $\operatorname{sex}(S: 1=$ male, and $2=$ female), age ( $A$, years), arm length, and half-span. On the basis of these measurements, five equations were developed to predict weight and two equations were developed to predict height, being simplified on the basis of the larger number of variables and the need for equipment (Table 2). Table 2 shows the average $\%$ error, its standard deviation and 10th, 25th, 50th and 75th percentiles. As an example for clarification, the prediction obtained with equation I gave a mean error of $\pm 5.1 \%$ with a standard deviation of $6.6 \%$. In addition, $10 \%$ of the individual value had an estimated error of less than $0.6 \%\left(\mathrm{P}_{10}\right)$ and $75 \%$ of all estimates calculated with formula I had an error of $6.3 \%$ or less $\left(P_{75}\right)$, and so on. 
Table 1. Anthropometric characteristics and bioimpedance measurements (mean and standard deviation) HCFMRP and HUEC, 2004.

\begin{tabular}{|c|c|c|c|c|c|c|}
\hline \multirow{2}{*}{ Sample size $(n)$} & \multicolumn{2}{|c|}{368} & \multicolumn{2}{|c|}{$173(47 \%)^{*}$} & \multicolumn{2}{|c|}{$195(53 \%)^{* *}$} \\
\hline & mean*** & $S D^{*}$ & mean & SD & mean & SD \\
\hline Abdominal circumference $(\mathrm{AbC}-\mathrm{cm})^{* * * *}$ & 89.1 & 13 & 87.7 & 16 & 90.3 & 13 \\
\hline Age (years)§ & 49.0 & 16 & 46.6 & 17 & 51.0 & 16 \\
\hline Arm circumference $(\mathrm{AC}-\mathrm{cm})^{* * * *}$ & 28.0 & 5 & 28.6 & 5 & 28.8 & 4 \\
\hline Arm length $(A L-c m) \S$ & 36.4 & 2 & 35.0 & 2 & 37.7 & 2 \\
\hline Bicipital skin fold (BST - mm) & 9.5 & 6 & 12.7 & 7 & 6.7 & 4 \\
\hline Body mass index $\left(\mathrm{BMl}-\mathrm{kg} / \mathrm{m}^{2}\right)$ & 24.6 & 5 & 25.1 & 6 & 24.0 & 4 \\
\hline Calf circumference $(\mathrm{CC}-\mathrm{cm})^{* * *}$ & 33.9 & 4 & 33.5 & 5 & 34.2 & 4 \\
\hline Half span $(\mathrm{HS}-\mathrm{cm})^{\star * * *}$ & 83.4 & 5 & 79.6 & 5 & 87.0 & 4 \\
\hline Height $(\mathrm{H}-\mathrm{cm})$ & 163.1 & 9 & 156.8 & 7 & 168.9 & 7 \\
\hline Knee height $(\mathrm{KH} \mathrm{cm})$ & 50.4 & 4 & 48.1 & 3 & 52.4 & 3 \\
\hline Reactance (Rc - $\Omega$ ) & $62.0^{\mathrm{a}}$ & 16 & 64.0 & 14 & 59 & 17 \\
\hline Resistance $(\operatorname{Re}-\Omega)^{\star * * *}$ & $614.0^{\mathrm{a}}$ & 125 & 666.0 & 123 & 566.0 & 106 \\
\hline Subscapular skinfold (SST - mm)**** & 17.4 & 9 & 19.2 & 10 & 15.7 & 8 \\
\hline Suprailiac skinfold (IST - mm) & 17.3 & 10 & 19.6 & 11 & 15.7 & 7 \\
\hline Thumb adductor muscle (AMT mm) & 10.5 & 4 & 9.5 & 3 & 11.5 & 4 \\
\hline Tricipital Skin fold (TSF - mm) & 16.5 & 9 & 21.3 & 9 & 12.2 & 6 \\
\hline Weight $(\mathrm{W}-\mathrm{kg})$ & 65.5 & 15 & 61.6 & 14 & 68.9 & 14 \\
\hline
\end{tabular}

* From HCFMRP (Ribeirão Preto University Hospital); ** From HUEC (Curitiba Universtiy Hospital); *** Mean and standard deviation; **** Significant variable for weight and height prediction $(p<0.001$, see Table 2$) ;$ athe patients receiving intravenous hydration were excluded $(n=222)$.

Table 2. Equations proposed to predict height and weight based on the anthropometric measurements and bioimpedance.

\begin{tabular}{|c|c|c|c|c|c|c|c|}
\hline \multicolumn{8}{|c|}{ Equations for weight prediction $(\mathrm{kg})$} \\
\hline 0. & \multicolumn{7}{|c|}{$0.5149(\mathrm{H})+0.7416(\mathrm{AC})+0.308(\mathrm{AbC})+0.5317(\mathrm{CC})+0.364(\mathrm{SST})-0.0137(\mathrm{Re})-82.723$} \\
\hline 0. & \multicolumn{7}{|c|}{$0.4550(\mathrm{AC})+0.3867(\mathrm{AbC})+0.7826(\mathrm{CC})+0.2654(\mathrm{SST})-0.0238(\mathrm{Re})+1.6760$} \\
\hline 0. & \multicolumn{7}{|c|}{$0.5030(\mathrm{AC})+0.5634(\mathrm{AbC})+1.3180(\mathrm{CC})+0.0339(\mathrm{SST})-43.1560$} \\
\hline IV & \multicolumn{7}{|c|}{$0.4808(\mathrm{AC})+0.5646(\mathrm{AbC})+1.3160(\mathrm{CC})-42.2450$} \\
\hline$\vee$ & \multicolumn{7}{|c|}{$0.5759(A C)+0.5263(A b C)+1.2452(C C)-4.8689(S) \pm 32.9241$} \\
\hline \multicolumn{8}{|c|}{ Equations for height $(\mathrm{cm})$} \\
\hline $\mathrm{Vl}$ & \multicolumn{7}{|c|}{$58.6940-2.9740(\mathrm{~S})-0.0736(\mathrm{~A})+0.4958(\mathrm{AL})+1.1320(\mathrm{HS})$} \\
\hline VII & \multicolumn{7}{|c|}{$63.525-3.237(\mathrm{~S})-0.06904(\mathrm{~A})+1.293(\mathrm{HS})$} \\
\hline \multicolumn{8}{|c|}{ Statistical data - actual x predict } \\
\hline Equations & $\mathrm{R}_{\text {multiple }}$ & Average $\%$ error* & Standard deviation & $\mathrm{P}_{10}{ }^{* *}$ & $P_{25}$ & $P_{50}$ & $P_{75}$ \\
\hline । & 0.9457 & 5.1 & 6.6 & 0.6 & 1.4 & 3.3 & 6.3 \\
\hline$\|$ & 0.9005 & 8.0 & 7.2 & 1.6 & 3.2 & 6.5 & 10.7 \\
\hline III & 0.9272 & 7.0 & 5.9 & 1.0 & 2.5 & 5.4 & 10.2 \\
\hline IV & 0.9271 & 6.7 & 5.6 & 1.1 & 2.4 & 5.4 & 9.6 \\
\hline V & 0.9414 & 6.0 & 5.0 & 1.0 & 2.1 & 4.7 & 8.0 \\
\hline $\mathrm{Vl}$ & 0.8809 & 2.1 & 1.7 & 0.3 & 0.8 & 1.8 & 3.1 \\
\hline VII & 0.8765 & 2.2 & 1.7 & 0.4 & 0.8 & 1.7 & 3.2 \\
\hline
\end{tabular}

$A=$ age (years); $A b C=$ abdominal circumference $(\mathrm{cm}) ; A C=$ arm circumference $(\mathrm{cm}) ; A L=$ arm length $(\mathrm{cm}) ; C C=$ calf circumference; $\mathrm{H}=$ height $(\mathrm{m})$; $\mathrm{HS}=$ half $\operatorname{span}(\mathrm{cm}) ; \mathrm{Re}=$ resistance $(\Omega) ; \mathrm{S}=\operatorname{sex}(1=$ male and $2=$ female); SST= subscapular skinfold $(\mathrm{mm})$; * The mean percent error from the actual value. This table shows the average \% error, its standard deviation and 10th, 25th, 50th and 75th percentiles; ** Percentile. 
Table 3. Statistical evaluation of weight and height obtained from the literature prediction equations and compared to the paired actual value.

\begin{tabular}{|c|c|c|c|}
\hline \multirow{2}{*}{ Equations } & \multicolumn{2}{|c|}{ Weight (kg) } & \multirow{2}{*}{$\begin{array}{c}p \text { value } \\
\text { actual } x \text { predicted value }\end{array}$} \\
\hline & mean & SD & \\
\hline Actual sample weight & 65.53 & 14.7 & \\
\hline Chumlea et al. ${ }^{8}$ & 59.71 & 15.4 & $<0.001$ \\
\hline Proposal I* & 63.44 & 13.9 & $\mathrm{Ns}^{* *}$ \\
\hline Proposal II* & 63.47 & 13.3 & Ns \\
\hline Proposal III* & 65.68 & 13.1 & Ns \\
\hline Proposal IV* & 65.46 & 13.1 & Ns \\
\hline \multirow[t]{2}{*}{ Proposal V* } & 65.47 & 13.8 & Ns \\
\hline & \multicolumn{2}{|c|}{ Height $(\mathrm{cm})$} & \\
\hline Actual sample height & 163.1 & 9.3 & \\
\hline Chumlea et al. ${ }^{6}$ & 165.0 & 7.4 & $<0.001$ \\
\hline Mitchell \& Lipschitz ${ }^{8}$ & 166.0 & 11.0 & $<0.001$ \\
\hline Proposal VI* & 163.2 & 8.2 & Ns \\
\hline Proposal VII* & 162.7 & 8.2 & 0.033 \\
\hline
\end{tabular}

* Equations described in Table 2; ** ns = no significant difference between the estimated against the paired actual value ( $p>0.05)$; SD: standard deviation.

The equations for weight and height estimates proposed in the present study were tested against those described in the literature in terms of their adequacy for the prediction of weight and height (Table 3).

\section{DISCUSSION}

The difficulties in constructing equations from anthropometric data for the prediction of weight and height are important because they may compromise the estimate of weight and height of bedridden immobilized patients. In addition, another possible limitation of the use of these equations is the availability of the necessary equipment. Scales for weighing a patient in bed, electrical bioimpedance and adipometers are not part of the reality of most health institutions ${ }^{13}$. For the purpose of this prediction, the equation described by Chumlea et al. ${ }^{4}$ was developed based on a sample of white American elderly subjects and its application to persons of other ages and races may be compromised. Sampaio et al. ${ }^{13}$ obtained concordant results for weight estimate by the equation of Chumlea et al. ${ }^{4}$ and actual weight for patients from Fortaleza, Brazil. However, the characteristics of the Fortaleza sample were different from those of the present patients even though the mean age of the patients in the two studies was similar. The Fortaleza patients were shorter and thinner, with a mean BMl of $22 \mathrm{~kg} / \mathrm{m}^{2}$, compared to the present patients, whose mean BMI was $24 \mathrm{~kg} / \mathrm{m}^{2}$. As confirmed in the present study, when this equation ${ }^{4}$ was applied to this sample, the mean was statistically different from the actual one.

In view of these limitations, new equations were developed for weight prediction. The first equation takes into consideration anthropometry and bioimpedance, and three instruments are needed to collect the data: an adipometer, a measuring tape and an electrical bioimpedance analyzer. In addition, this equation requires knowing the height of the patient. Although it showed the best general correlation with actual weight, it was not appropriate for patients with a BMI of more than $30 \mathrm{~kg} / \mathrm{m}^{2}$. In view of the complexity involved in making the measurements and the number of instruments necessary, the equations were simplified starting from equation I to $V$, with a gradual removal of measurements according to the complexity of their execution. 
On this basis, equation 2 does not require previous knowledge of an individual's height and does not present limitations of its use according to BMI. Equation 3 does not require the use of bioimpedance. Equations 4 and 5 only require a flexible measuring tape and the sex of the patient to estimate weight and height, and also do not show a significant difference according to BMI.

Methods for the estimate of body composition such as bioimpedance have limitations when they are applied to patients with excess body fat since obese individuals present a significantly increased proportion of fluid compared to non-obese individuals ${ }^{14}$. This factor may explain why equation I was not appropriate for obese patients.

Regarding skinfold, there are technical difficulties for the measurements because of the morphological changes caused by the excess of adipose tissue in obese individuals. In addition, an excessive opening of the caliper may change the pressure of the compressible spring, with a consequent significant underestimate of the results. Another difficulty regarding the application of this technique is to find the bone protuberances that direct the identification of the standard site for skin fold measurement ${ }^{14}$. These technical difficulties may compromise the variable measurement to be applied in three of the equations suggested in the present study and in the equation described by Chumlea et al. ${ }^{4}$.

Circumference measurements used in equations 4 and 5 , obtained with a measuring tape, were found to provide a practical method for weight estimate with an error of less than 10\% for $75 \%$ of the individuals evaluated (Table 2). Height estimate based on knee height is a technique with limitations when the lower limbs are immobilized, especially for trauma patients. In addition, there are differences between actual height and height estimated by these equations $s^{6,8}$ which may be explained by the fact that both equations were developed for, and evaluated in, elderly people. Height loss is detected over the years and the application of these formulas to individuals in other age ranges is not recommended ${ }^{15}$. Thus, age becomes a fundamental factor for the estimate of height.

Information about patient height is important for the evaluation of nutritional status and for the prediction of energy expenditure. On this basis, two equations were developed for height estimate of patients of both sexes, older than 18 years. Both equations consider age and sex as variables. Equation 6 also used two measurements, i.e., arm length and half-span, which can be obtained simply by using a measuring tape. Equation 7 uses the measurement of the half-span to estimate the height of an individual, as is also the case for the method suggested by Mitchell \& Lipschitz ${ }^{8}$. The method suggested by these authors, however, yields measurements that differ significantly from actual height, a fact that makes their use unviable.

Both the equations for the estimate of weight and height can be used according to the needs of the patient, with equation 6 being suggested for patients whose lower limbs are immobilized. They can be options for institutions that are not equipped with bed scales and stadiometers.

\section{CONCLUSION}

The application of weight and height predicting equations that use a measuring tape as the only tool is a viable, simple and safe alternative for the estimation of weight and height of bedridden individuals temporarily or definitively unable to walk. Complementary studies are needed to evaluate the applicability of these equations to the estimate of weight and height in other samples from the same region and from other regions of Brazil.

\section{ACKNOWLEDGMENTS}

The authors wish to thank the head of the Service of Nutrition and Diet of Hospital Universitário Evangélico de Curitiba, Karina K. Paciornick, and the other nutritionists of this service for receptivity and 
collaboration, and Conselho Nacional de Desenvolvimento Científico e Tecnológico (CNPq), Coordenação de Aperfeiçoamento de Pessoal de Nível Superior (CAPES) and Fundação de Amparo à Pesquisa do Estado de São Paulo (FAPESP) for partial financial support of this study.

\section{REFERENCES}

1. Hardman JG, Limbird LE, Gilman AG. Goodman and Gilman's. The pharmacological ba-sis of therapeutics. New York: McGraw-Hill; 1996.

2. Leary TS, Milner QJW, Nilblett DJ. The accuracy of the estimation of body weight and height in the intensive care unit. Eur J Anaesthesiol. 2000; 17(11):698-703.

3. Onis M, Habicht JP. Anthropometric reference data for international use: recommenda-tion from a World Health Organization Expert Committee. Am J Clin Nutr. 1996; 64(4):650-8.

4. Chumlea WC, Guo S, Roche AF, Steinbaugh ML. Prediction of body weight for the non-ambulatory elderly from anthropometry. J Am Diet Assoc. 1988; 88(5):564-8

5. Heymsfield SB, Baugmgartner RN, Sheau-Fang P. Avaliação nutricional da desnutrição por métodos antropométricos. In: Shils ME, Olson JA, Shike M, Ross AC. Tratado de nutrição moderna na saúde e na doença. São Paulo: Manole; 2003.

6. Chumlea WC, Roche AF, Steinbaugh ML. Estimating stature from knee height for persons 60 to 90 years of age. J Am Geriatr Soc. 1985; 33(5):116-20.

7. Frisancho AR. New norms of upper limb fat muscle areas for assessment of nutritional status. Am J Clin Nutr. 1981; 34(11):2540-5.
8. Mitchell CO, Lipschitz DA. Arm length measurement as an alternative to height in nutri-tional assessment of the elderly. J Parentr Enteral Nutr. 1982; 6(3):226- 9.

9. Durnin JV, Womersley J. Body fat assessed from total body density and its estimation from skinfold thickness: measurements on 481 men and women aged from 16 to 72 years. Br J Nutr. 1974; 32(1):77-97.

10. Gerude MF. Musculatura adutora do polegar: Um novo parâmetro antropométrico [dissertação]. Rio de Janeiro: Universidade Federal do Rio de Janeiro; 2003.

11. Baumgartner RN, Chumlea WC, Roche AF. Estimation of body composition from bio-electric impedance of body segments. Am J Clin Nutr. 1989; 50(2):221-6.

12. Zar JH. Bioestatistical analysis. 2nd ed. New Jersey: Prentice-Hall; 1987.

13. Sampaio HAC, Melo MLP, Almeida PC, Benevides ABP. Aplicabilidade das fórmulas de estimativa de peso e altura para idosos e adultos. Rev Bras Nutr Clín. 2002; 17(4):117-21.

14. Cezar C. Limitações metodológicas e dificuldades práticas para avaliação da composição corporal em obesidade moderada e grave. Rev Bras Nutr Clín. 2002; 17(4):143-8.

15. Dey DK, Rothenberg E, Sundh V, Bosaeus I, Steen B. Height and body weight in the elderly 25 year longitudinal study of population aged 70 to 95 years. Eur J Clin Nutr. 1999; 53(12):905-14.
Received on: 1/7/2005

Final version resubmitted on: 1/9/2006 Approved on: 3/10/2006 
